\title{
Does Maternal Education Really Improve Child Health?
}

\author{
${ }^{1}$ Dr. Vaitheeswaran Natarajan, ${ }^{2}$ Dr. Devaki .P.R. \\ 1.Senior Assistant Professor, Department of Pediatrics \& Government Royapettah Hospital \&Kilpauk \\ Medical College, The Tamilnadu Dr. M.G.R. Medical University Chennai-600014, Tamilnadu, India. \\ 2. Associate Professor, Department of Physiology, Sree Balaji Medical College, Chromepet, Bharath university \\ Chennai-600044.Tamilnadu ,India.
}

\begin{abstract}
Maternal education plays an important role in determination of child's health. It may affect the nutritional status of the child. The nutritional status depends on many factors including the incidence of morbidity and personal hygiene.
\end{abstract}

Aim \&objective: The aim of this study was to analyze the impact of maternal education on child's health, incidence of morbidity and personal hygiene.

Materials and Methodology: 449 mothers with their children who were in the age group of 0-6 years were included in the study. Proforma was given to obtain information about the about the socioeconomic status, educational qualification. Anthropometric measurements were taken in children .Grading of PEM was done based on the weight for age using IAP classification.

Results: Maternal education influences the health of the child by improving the nutritional status . However, personal hygiene and incidence of morbidity was not influenced by the educational status of the mother.

Key words-Maternal education, nutritional status

\section{INTRODUCTION}

Education plays a very important role in determining the socioeconomic status, occupation and lifestyle which in turn greatly influences the income, housing and other material resources [1]. In a study done by Racine et al it was found that $15 \%$ of the poorest mothers have problem with basic literacy and it was estimated that each additional year of schooling increase a women's income by 10-20 percent which in turn has a direct impact on the child's health[2].

Maternal education was found to play an important role in improving the child survival and health in developing countries [3] This can be attributed to the fact that educated mothers have a better knowledge about health care, nutrition and may provide a healthy sanitary habits and safer environment for their children [4].

The National Research Council and Institute of Medicine, (2004) has defined child health as the extent to which children are able or enabled to develop and realize their potential, satisfy their needs and develop the capacities that allow them to interact successfullywith the biological, physical and social environment.

In a study done by Barrera et al they have predicted that maternal education has the greatest impact on child health especially among the children of age group0-2 years. Improving female education is important for reducing childhood mortality rate[5].This is the reason for emphasizing the education of girl child. Studies have shown that the use of basic Health facilities that relate to childhood survival has a direct relationship with mothers education. Hence the aim of the study was to analyze the impact of maternal education on Nutritional Status, Morbidity factors - Diarrhoea, Respiratory infections and Personal hygiene.

\section{MATERIALS AND METHODOLOGY}

449 mothers with their children who were in the age group of 0-6 years were included in the study. This study was carried out in ICDS Covered slums in Anganwadi centers. A detailed Proforma was given to obtain information about the about the socioeconomic status, educational qualification. Anthropometric measurements were taken in children .Grading of PEM was done based on the weight for age using IAP classification.

\section{IAP Classification}

$\begin{array}{ll}\text { 1st Degree } & \mathbf{8 0}-\mathbf{7 0 \%} \\ \text { 2nd Degree } & \mathbf{7 0}-\mathbf{6 0} \% \\ \text { 3rd Degree } & \mathbf{6 0}-\mathbf{5 0 \%} \\ \text { 4th Degree } & <\mathbf{5 0 \%} \text { of Expected }\end{array}$

The Proforma included details about the episodes of diarrhoea, respiratory infections, cleanliness - skin, hair, nails, daily bath, brushing. For practical purposes mothers were classified into 4 groups based on their 
educational qualification . Group 1- Illiterate,Group 2- Up to grade 4(Primary education), Group 3- Grade 510,Group- 4-11th ,Grade and above.

III. RESULTS

TABLE -1 - NUMBER OF CHILDREN UNDER EACH GROUP OF MOTHERS WHO WERE CLASSIFIED ON THE BASIS OF THEIR EDUCATION

\begin{tabular}{|l|l|}
\hline & NUMBER OF CHILDREN \\
\hline GROUP-1 & 190 \\
\hline GROUP-2 & 65 \\
\hline GROUP-3 & 177 \\
\hline GROUP-4 & 17 \\
\hline
\end{tabular}

TABLE -2- NUMBER OF CHILDREN IN EACH GRADE OF PROTEIN ENERGY MALNUTRITION

\begin{tabular}{|l|l|}
\hline Normal & $180(40.1 \%)$ \\
\hline Grade -1 PEM & $170(37.9 \%)$ \\
\hline Grade -2 PEM & $84(18.7 \%)$ \\
\hline Grade -3PEM & $14(3.1 \%)$ \\
\hline Grade -4 PEM & $1(0.2 \%)$ \\
\hline
\end{tabular}

TABLE -3 -COMPARISON OF MOTHERS EDUCATION WITH GRADES OF PEM

\begin{tabular}{|c|c|c|c|c|c|}
\hline & Illiterate & Primary & $5^{\text {th }}-10^{\text {th }}$ & $11^{\text {th }} \&$ above & Total \\
\hline Normal & $57(30 \%)$ & $25(38.5 \%)$ & $86(48.6 \%)$ & $12(70.6 \%)$ & $180(40.1 \%)$ \\
\hline Grade I & $84(44.2 \%)$ & $23(35.4 \%)$ & $59(33.3 \%)$ & $4(23.5 \%)$ & $170(37.9 \%)$ \\
\hline Grade II & $43(22.6 \%)$ & $14(21.5 \%)$ & $26(14.7 \%)$ & $1(5 . .9 \%)$ & $84(18.7) \%$ \\
\hline Grade III & $6(3.2 \%)$ & $3(4.6 \%)$ & $5(2.8 \%)$ & & $14(3.1 \%)$ \\
\hline Grade IV & & & $1(0.6 \%)$ & & $1(0 . .2 \%)$ \\
\hline Total & $190(100 \%)$ & $65(100 \%)$ & $177(100 \%)$ & $17(100 \%)$ & $449(100 \%)$ \\
\hline
\end{tabular}

FIGURE 1: COMPARISON OF MOTHERS EDUCATION WITH GRADES OF PEM

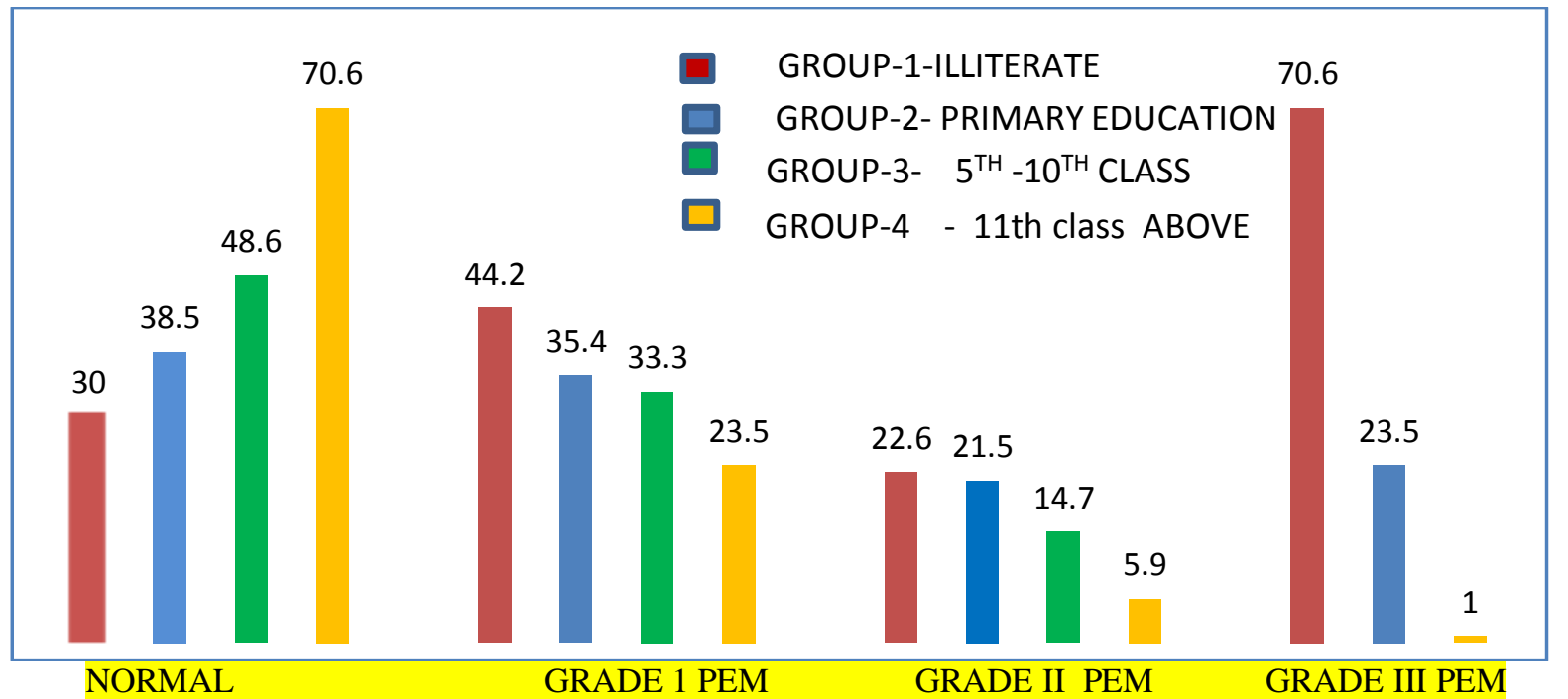




\section{DISCUSSION}

In this study it was observed that as the educational status of the mother improved there was a decrease in the percentage of children with severe grade of protein energy malnutrition. Out of 449 children only one child had grade IV PEM (TABLE-2). The percentage of distribution of normal children were more $(70.6 \%)$ in group 4 which included the mothers whose educational status was 11 standard and above. It was observed that the percentage of grade I and grade II protein energy malnutrition was more in group 1 mothers $44.2 \%$ and 22.6\% respectively. Group 1 includes illiterate mothers. In Group 2 and Group 3 mothers the percentage of distribution of grade 1 malnutrition was almost the same(FIGURE -1). The percentage of distribution of grade 3 PEM was more in Group- 1 mothers (70.6\%). This results indicate that the higher the educational qualification better the nutritional grade.

In this study the environmental condition were same for all the mothers. The observed results may be due to the fact that maternal education has created awareness in the mothers regarding the access to the health delivery system and nutrition during illness. This possibly could be the reason for the improved health status observed in the children of mothers with better education. However it was observed that mothers education did not affect the incidence of morbidity factors like respiratory infections, diarrohoeal episodes in the children . The incidence was almost the same in children of different groups of mothers. This may be due to the poor environmental condition prevailing in the slums. Despite the increased occurrence of morbidity factors these factors has not affected the nutritional status in group 4. This may be due to the fact that as the mother was educated there was increased awareness among mothers regarding the nutrition during illness. However, it was observed that the general education does not completely change the personal hygienic behavior of our population as no correlation was found between mother's educational status and personal hygiene.

On exploring other factors which possibly would have affected the nutritional status in the children of better educated mothers, it has been reported that breast feeding is of considerable importance for nutrition and development [6]. Skafida etal acknowledges the importance of maternal education on breastfeeding and found that higher educational qualifications are associated with an increased rate of breast feeding take up [7].

Child hood immunizations also play an important role in determining the heath of the children especially in reducing the incidence of morbidity. Childhood immunization are also shown to have a poorer uptake rates in women of low literacy level [8].

In a study done Sleath et al they have found that younger mothers with lower literacy skills are more likely to report a barrier for giving medication to the children and also found it difficult to access the health service[9].

\section{CONCLUSION}

Hence in conclusion, maternal education definitely has a positive influence on the health of the child by improving the nutritional status of the child. However, it does not affect the morbidity factors and does not play a role in improving the personal hygiene.

Further studies are needed to explore the influence of other factors like the age of the mother, traditional practices and superstitious belief of the mother and its influence on the child health so that we can directly correlate the influence of maternal education on the child's health.

Further, as maternal education has not affected the incidence of morbidity and the personal hygiene it may be highlighted that environmental conditions have to be improved to make a child healthy .Also, health education and behavioral modification are to be recognized as separate entity and should be incorporated into the curriculum of general education .

\section{REFERENCES}

[1] Feldman, J et al. 1989. National trends in educational differentials in mortality. American Journalof Epidemiology 129, pp. 919933.

[2] Racine, A and Joyce, T. 2007. Maternal education, child immunisations and public policy :evidence from the US national immunisation survey. Social science and medicine 65, pp. 1765-1772

[3] Caldwell J. Education as a factor in mortality decline: an examination of Nigerian data. Population Studies. 1979; 33: 395-413.

[4] Strauss J, Thomas D. Health, nutrition and economic development. Journal of Economic Literature. 1998; $36(2)$ : 766-817.

[5] Barrera, A. 1990. The role of maternal schooling and its interaction with public health programs in child health production. Journal of Development Economics 32, pp. 69-91.

[6] Stanley, I et al. 2007. Breastfeeding and maternal and infant health outcomes in developed countries. Evidence Reports/Technology Assessments, No.153.[Online].

[7] Skafida, V. The relative importance of social class and maternal education for breast feeding initiation. Public Health Nutrition.2009; 12: 2285-2292.

[8] Wilson, F et al. 2006. Can easy-to-read immunizations information increase knowledge in urban low-income mothers? Journal of Pediatric Nursing 21, pp. 4-12.

[9] Sleath, B et al. 2006. Literacy and perceived barriers to medication taking among homelessmothers and their children. Am J HealthSyst Pharm 63, pp. 346-351? 